\title{
EDUCATOR COMPETENCIES OF PRE-SENIOR PREPARATION
}

\section{[KOMPETENCIE EDUKATORA PRESENIORSKEJ PRIPRAVY]}

\author{
Michal Koricina
}

doi: 10.18355/PG.2021.10.1.4

\begin{abstract}
Pre-Senior Education will be one of the main pillars of active ageing policy in the future. Requirements on adult educators, lecturers, trainers of older people, grow. In the paper author presents theoretical starting points of competencies of educator of pre-senior preparation, deals with general competencies defined in Slovak national documents and indicates specific requirements on older adult educator. He also talk about aspects as relational competence and charizma of lecturer which are important elements of quality of educational event. The article is the output of author within the project VEGA no.1/0001/18 called Preparation for ageing and old age - possibilities of andragogical intervention.
\end{abstract}

\section{Key words}

Educator of Adults, Competencies, Pre-senior preparation

\section{Anotácia}

Preseniorská edukácia bude jedným z hlavných pilierov politiky aktívneho starnutia v budúcnosti. Požiadavky na andragóga, ktorý je lektorom, školitel'om či trénerom v oblasti vzdelávania starších dospelých l'udí, stúpajú. Autor v príspevku predstavuje teoretické východiská kompetencií edukátora preseniorskej prípravy, zaoberá sa všeobecnými spôsobilost’ami definovanými v národných dokumentoch Slovenska a uvádza tiež špecifické požiadavky na vzdelávatel'a starších dospelých. Venuje sa tiež aspektom ako vzt’ahová kompetencia a charizma lektora, ktoré sú dôležitými prvkami kvality vzdelávacieho podujatia. Článok je výstupom v rámci projektu VEGA č.1/0001/18 s názvom Príprava na starnutie a starobu - možnosti andragogickej intervencie.

\section{Kl’účové slová}

Edukátor dospelých, Kompetencie, Preseniorská príprava

\section{Úvod}

Otázka aktívneho starnutia starších dospelých l’udí sa stáva čoraz viac aktuálnejšou vo viacerých oblastiach. Inak tomu nie je ani na poli vzdelávania, ktoré predstavuje jeden z dôležitých pilierov prípravy na odchod do starobného dôchodku. Pod pojmom preseniorská edukácia rozumieme predovšetkým krátkodobú prípravu na odchod do dôchodku, ktorá začína približne 5 rokov pred samotným odchodom a jej ciel'om je predovšetkým dosiahnutie sociálnej istoty a pocitu bezpečnosti pri prechode do dôchodku (Cornanicova, 2007). Ak má byt' toto obdobie v živote staršieho človeka 
úspešné, je na mieste zaoberat' sa otázkou kvality preseniorského edukačného programu.

\section{Kompetencie edukátora starších dospelých}

Jedným z klúčových aktérov prípravy na starobný dôchodok je edukátor. Môžu ho označovat' pojmy ako lektor, facilitátor či mentor, no jeho úloha ostáva stále rovnaká - pomôct' starším dospelým l'ud'om pripravit' sa na obdobie dôchodku, aby prechod do novej životnej etapy zvládli úspešne. Ciel'om nášho príspevku je preto ponúknut' kompetenčný profil andragóga, ktorý by mal pôsobit' $\mathrm{v}$ organizáciách či podnikoch za účelom edukačnej prípravy zamestnancov na starnutie, starobu, odchod z pracovného života po dosiahnutí dôchodkového veku a tiež za účelom pomoci týmto l'ud’om objavit’ potenciál ich nastávajúceho životného štýlu.

V. Kupcová (2014, p. 108) zarad’uje osobnost' lektora medzi štyri základné determinanty kvality vzdelávacieho podujatia, preto je potrebné, aby sa profilovaniu jeho kompetenčného modelu venovala dostatočná pozornost', o to viac, že ciel'ová skupina starších dospelých so sebou prináša vlastné špecifiká, ktoré je potrebné zohl'adnit' pri edukačnom procese.

Kompetencia predstavuje určitý súbor, kombináciu či nazhromaždenie znalostí, schopností, spôsobov správania, prístupu, porozumenia, spôsobov sebarealizácie a pod. (Pejatović, A., 2012, p. 95).

M. Despotović (2012) poukazuje na to, že systém vzdelávania dospelých je dynamický a vel'mi heterogénny odbor l'udskej činnosti. $Z$ toho vyplýva viacero faktorov, od ktorých sa odvíja pracovná funkcia, rola pracovníkov aj druh kompetencií vzdelávatel’ov dospelých. Medzi tieto faktory patria:

- Oblast' vzdelávania - rozlišuje sa, či ide o vzdelávanie všeobecné, odborné, kultúrne, alebo umelecké.

- Užšia oblast’ vzdelávania - definuje, o akú tému vzdelávania ide napríklad získavanie odborných zručností, starostlivost' o zdravie, ochrana životného prostredia, ochrana l'udských práv, informačné a komunikačné technológie, sociálne zručnosti, osobnostný rozvoj a d'alšie.

- druh vzdelávania a učenia - iné kompetencie edukátora si vyžaduje učenie formálne, iné neformálne a iné informálne.

- Inštitúcie a organizácie, ktoré realizujú vzdelávanie - postavenie andragóga sa líši aj v závislosti od inštitucionálneho zabezpečenia (vzdelávacie organizácie, kultúrne organizácie, štátne orgány, neziskové subjekty, cirkev,...).

- Pracovné pozície zamestnancov - kompetencie sú ovplyvňované aj tým, akú pozíciu andragóg zastáva (učitel', školitel', lektor, organizátor, animátor, manažér).

- Dominantné roly a úlohy - potrebné kompetencie určujú aj úlohy, ktoré sú hlavnou náplňou práce andragóga (plánovanie vzdelávacích aktivít, konzultácie a poradenstvo, hodnotenie, koučovací prístup a mentoring,...). 
- Cielové skupiny, ktorým je vzdelávanie určené - v našom prípade skupina starších dospelých l'udí, ktorá prináša so sebou aj určité špecifické nároky na lektora (Despotović, M. 2012, p. 83).

Pri definovaní základných profesijných kompetencií andragóga, pôsobiaceho $\mathrm{v}$ oblasti edukačnej prípravy zamestnancov na starobný dôchodok, vychádzame z Národnej sústavy povolaní Slovenskej republiky, $\mathrm{v}$ rámci ktorej zameriavame pozornost' na povolania lektora d'alšieho vzdelávania a sociálneho pracovníka, ked’že charakter práce andragóga so staršími dospelými l'ud'mi do určitej miery zahŕňa kompetencie oboch týchto povolaní. Aj na základe toho teda môžeme tvrdit', že všeobecnými spôsobilost’ami a kompetenciami edukátora starších dospelých určite sú:

- Komunikácia (jednanie s l'ud'mi) - je dôležité, aby lektor komunikoval s účastníkmi profesionálne i l'udsky, a tak bol pre nich partnerom, ktorý im v procese edukácie pomáha a ul'ahčuje im ho.

- Motivovanie l'udí - schopnost' motivovat' a nadchnút' účastníkov je pri tomto type vzdelávania kl'účová. Lektor musí byt' tým, kto im odkryje potenciál a benefity d’alšieho vzdelávania aj vo vyššom veku.

- Osobnostný rozvoj - andragóg by mal byt' zorientovaný voblasti osobnostného rozvoja a mal by ovládat' techniky, ktorými účastníkom pomôže nájst' možnosti ich vlastného d'alšieho rastu. A ked’že vedenie príkladom je jednou z účinných metód, aj sám andragóg by nemal zabúdat' na svoj rozvoj po viacerých stránkach.

- Samostatnost - vedenie procesu edukácie si vyžaduje autonómneho lektora, ktorý je schopný bez d’alšej pomoci usmerňovat' edukantov na ceste k stanoveným ciel'om.

- Kultivovaný slovný prejav, schopnost' vyjadrovania sa - pri starších dospelých je neraz potrebné rozprávat' pomalšie, dôležité informácie zopakovat', termíny prevzaté z cudzieho jazyka vysvetlit', a k tomu je nevyhnutné, aby lektor rešpektoval svojich poslucháčov a komunikoval s nimi jasne a zrozumitel'ne.

- Organizovanie a plánovanie práce - vedúci vzdelávacej aktivity by mal disponovat' tiež organizačnými schopnostami, aby efektívne naplánoval celý proces počnúc mapovaním vzdelávacích potrieb, cez realizáciu a evaluáciu účastníkov, až po hodnotenie efektívnosti celého programu.

- Prezentovanie - ked’že značná čast' vzdelávacieho programu spočíva aj v sprostredkúvaní nových poznatkov účastníkom, andragóg by mal poznat' zásady efektívnej prezentácie a vhodne ich aplikovat' pri svojej práci.

- Tvorivost', kreativita - špecifickost' ciel'ovej skupiny si vyžaduje, aby lektor disponoval určitou mierou kreativity a mohol tak zvolit' inovatívne metódy a postupy, ktoré účastníkov zaujmú a pomôžu im dosahovat' dobré výsledky.

- Vodcovské schopnosti - koncept andragóga ako lídra by nemal byt' cudzí edukátorovi, ktorý pracuje so staršími dospelými. Mal by vediet' predstavit' účastníkom víziu či smer, ktorým sa ich vzájomné pôsobenie bude uberat' a s ohl'adom na ich schopnosti posúvat' celý proces vpred. 
- Schopnost' prijímat' rozhodnutia a niest' zodpovednost' - aj ked' tento typ vzdelávania je charakteristický svojou neformálnostou, v určitých chvíl'ach by mal byt' lektor ten, kto urobí rozhodnutie a pevne si za ním stojí, samozrejme mysliac na konkrétnych edukantov, ktorých sprevádza (Národná sústava povolaní SR, 2021).

Dá sa povedat', že uvedené kompetencie a spôsobilosti by mali byt' „povinnou výbavou“ každého lektora. M. R. Patrício a A. J. Osório (2013) definujú 4 roly, ktoré by mal lektor $\mathrm{v}$ tejto oblasti zastávat'. Mal by:

- facilitovat' a motivovat' starších dospelých ku vzdelávaniu sa počas celého obdobia dôchodku,

- hl'adat' spôsoby, ako zapojit' čoraz viac starších dospelých,

- učit', sprevádzat', motivovat' a byt' trénerom pre starších dospelých,

- neustále zvyšovat' kvalitu vzdelávania dospelých (Patrício, M. R., Osório, A. J., 2013, p. 1).

Komparatívna výskumná štúdia Buiskoola a kol. (2010, in: Despotović, M., 2012) priniesla súhrn špecifických kompetencií, ktoré by mali byt' príznačné pre profesionálneho vzdelávatela dospelých. Sú nimi:

$>$ schopnost' posúdit' vzdelávacie potreby,

$>$ vytváranie postupu učenia (sa),

$>$ podpora nadobúdania vedomostí a podpora rozvoja dospelých účastníkov,

$>$ hodnotenie vzdelávacieho procesu,

$>$ vytváranie programu,

$>$ poradenstvo,

$>$ riadenie finančných zdrojov,

$>$ riadenie l'udských zdrojov,

$>$ vedenie inštitúcie,

$>$ propagácia inštitúcie,

$>$ administratívna podpora inštitúcie,

> tvorba vzdelávacieho prostredia, založeného na IKT (Buiskool a kol., 2010; Despotović, M., 2012, p. 85).

$Z$ vyššie uvedeného je zrejmé, že rozsah činností aj kompetencie andragóga sú vel'mi rozmanité.

Autorka H. Ko (2020) na základe svojho výskumu formulovala niekol'ko požiadaviek na osobnost' lektora, ktorý sa venuje primárne ciel'ovej skupine starších dospelých:

- Lektor by mal rozumiet' účastníkom na viacerých úrovniach (na úrovni fyzickej, psychologickej, sociálnej, emocionálnej, kultúrnej i rodovej). To predpokladá dlhší proces prípravy, ako je to pri vzdelávaní mladších ciel’ových skupín.

- Lektor by mal vediet' pomôct' účastníkom, ktorí majú určité t'ažkosti ešte predtým, než sami požiadajú o pomoc. Je tu potrebná značná miera empatie a vnímavosti, aby lektor zachytil aj potenciálne prekážky učiacich sa. 
- Dobrý lektor by mal učiacim sa pomáhat' prostredníctvom edukácie vyriešit' ich životné problémy. Je pravdou, že čím viac sa dotýka edukácia života l'udí, tým vyššiu hodnotu pre nich má.

- Lektor by sa mal snažit' povzbudzovat' vytváranie silných vzt'ahov medzi účastníkmi navzájom, ako aj ním a účastníkmi vzdelávania.

- Lektor by mal v maximálnej možnej miere do procesu edukácie zapájat' aj každého účastníka individuálne.

- Vo vel'kej miere by mal lektor využívat' praktické aktivity, aby účastníkov vtiahol do deja.

- Vychádzajúc zo stratégie „začat' so známym“ by mal lektor umožnit’ účastníkom vyjadrit’ to, čo už vedia, to, čo už zažili, aby na tom následne mohol stavat?

- Lektor by mal vediet' povzbudit' a využit' vlastnú (seba)stimuláciu učiacich sa, ktorá bola identifikovaná ako najsilnejší determinant spôsobujúci rozdiely medzi účastníkmi (Callahan, J. S. et al., 2003, p. 667).

- V priebehu vzdelávacej aktivity by mal lektor znižovat' závislost' účastníkov na ňom a viac podporovat' vzájomné učenie sa.

- Lektor by mal vytvárat' príležitosti pre účastníkov na vzájomné odovzdávanie si skúseností, podporovanie sa a vytváranie vzt’ahov s ostatnými účastníkmi vzdelávacej aktivity (Ko, H., 2020, p. 10).

Ak hovoríme o špecifických požiadavkách na andragóga, pracujúceho so staršími dospelými, pokladáme za potrebné zdôraznit' ešte jeden aspekt edukácie, ktorým je vytváranie silných vzt'ahov. Lektor ako facilitátor by mal ciel'avedome a proaktívne posilňovat' vzt'ahy s učiacimi sa, a tým prispievat' $\mathrm{k}$ lepšej klíme v skupine. Môže na to využit' niektoré zo stratégií:

- Potvrdenie - inštruktor by mal svojich edukantov potvrdzovat', rešpektovat' ich identitu, nerozprávat' sa s nimi povýšenecky a vhodným spôsobom sa „dotknút"“ ich vnútra.

- Akceptovanie - lektor by mal prijímat' všetkých bez rozdielu a snažit' sa im vyhoviet', bez ohl'adu na etnickú príslušnost', národnost', pohlavie či socio-ekonomickú úroveň. Pri starších l'ud'och je dôležité akceptovat' aj ich zdravotné znevýhodnenia.

- Zainteresované zúčastňovanie sa - lektor musí byt' pozorný a pripravený „zachránit““ účastníka, ktorý má problém alebo niečo nevie, a ktorému by mohlo byt' nepríjemné niečo sa lektora spýtat' alebo vyhl'adat' pomoc.

- Využivanie času a prostriedkov - lektor by mal účastníkom dopriat' dostatočný čas pred alebo po vyučovaní, počas prestávok im umožnit' íst' na čaj a byt' l'ahko dostupný (napr. prostredníctvom elektronickej pošty).

- Prístupnost' - lektor by sa mal snažit' zbúrat' bariéry medzi ním a účastníkmi aj tak, že sa $\mathrm{k}$ nim bude správat' podobne ako k priatel’om alebo rodinným príslušníkom.

- Asertivita - okrem prístupnosti však je potrebné udržiavat' aj určité profesionálne hranice, čo sa dá dosiahnut' stanovením základných pravidiel na začiatku kurzu či pomenovaním si očakávaní od účastníkov. 
- Ostražitost' - inštruktor by mal vopred poznat' citlivé problémy skupiny (napr. etnická príslušnost', náboženstvo či názorové odlišnosti na určitú tému), aby sa $\mathrm{v}$ priebehu vzdelávania nedal stiahnut' do hádok a konfliktov s účastníkmi o takýchto problémoch (Ko, H., 2020, p. 6).

Sme presvedčení, že kreatívni a zorientovaní andragógovia budú dôležitými aktérmi prípravy starších l'udí na odchod do dôchodku a budú sa tak podiel'at' na úspešnom aplikovaní konceptu aktívneho starnutia do života spoločnosti.

V našom príspevku považujeme za podstatné tiež uviest' jednu kompetenciu, ktorá by mala rovnako charakterizovat' andragóga, pracujúceho so staršími dospelými, a ktorej sa výskumne venujú $\mathrm{B}$. Wahlgren a kol. (2016). Ide o vzt’ahovú kompetenciu alebo kompetenciu v oblasti rozvoja vzt’ahov. Preseniorská edukácia plní pre staršieho človeka vo vel'kej miere socializačnú funkciu, a preto každý lektor by mal vytvárat' príležitosti na to, aby edukácia napínala potreby účastníkov aj v oblasti vytvárania sociálnych vzt’ahov, zdiel’ania skúseností či podpory pri zvládaní životných problémov. Podl'a spomenutých autorov sú obsahom tejto kompetencie tri otázky:

1) kompetencia vo zvládaní konfliktov medzi účastníkmi v skupine,

2) kompetencia $v$ dávaní vd’ačnej spätnej väzby účastníkom,

3) kompetencia v rozprávaní edukantom o osobnom živote (mimo vzdelávacej aktivity) (Wahlgren, B. a kol., 2016, p. 306).

Edukátori zapojení do výskumu B. Wahlgrena a kol. (2016) potvrdzujú, že rozvoj kompetencie voblasti rozvoja vzt'ahov je pre edukačný proces mimoriadne dôležitý. Hovoria, že rozvoj tejto novej roly edukátorov a vzt'ahovú kompetenciu do vzdelávania je možné aplikovat' mnohorakým spôsobom. Výzvou podla nich ostávajú dve základné otázky, a to a) ako rozvíjat' nové vzt'ahy so študentmi, a b) ako udržat' vzt'ahy v prostredí akademickej kultúry, a zároveň v sociálne podporujúcom prostredí, v ktorom môžu študenti prekvitat'. Podla slov jedného z účastníkov výskumu, „sú tri veci, ktoré musí byt' edukátor dospelých schopný ponúknut': vytvárat' vztahy, manažovat' triedu / skupinu a byt' odborne kvalifikovaný; pričom je poradie dôležité" (Wahlgren, B. a kol., 2016, p. 309). Faktorom úspešnosti edukačnej aktivity tiež ostáva, ako dokážu lektori stimulovat' rozvíjanie vzt’ahov medzi účastníkmi aj mimo triedy. (Wahlgren B. a kol., 2016). Apelujeme preto na to, aby vzdelávatelia starších dospelých mali na zreteli význam a benefity vzt’ahovej kompetencie v kontexte rozvoja osobnosti a socializácie učiacich sa, ktorých sprevádzajú.

$\mathrm{V}$ predkladanom príspevku nechceme ostat' len pri tradičnom vymedzení kompetencií edukátora. Vzdelávatel' starších dospelých by mal disponovat' aj akousi pridanou hodnotou, ktorou $\mathrm{v}$ tomto kontexte rozumieme charizmu lektora. Vel'mi podnetným je príspevok autorov Y. Wua a kol. (2014), ktorí sa zaoberali otázkou, či charizma edukátora dospelých môže podnietit' záujem dospelých l'udí o účast' na d’alšom vzdelávaní. Besides, Wang (2012, in: Wu, Y. a kol., 2014, p. 397) uvádzajú definíciu pojmu osobnostná charizma, ktorá pod tento termín zahíña vedomosti, schopnosti, temperament, morálnu kultiváciu a prejavy správania (vonkajší faktor) obliekanie a reč tela. 
Autori d’alej uvádzajú, že vnútorná charizma edukátora pojíma tri faktory: 1 . vyučovacie metódy, 2. charakter, 3. vedomosti; vonkajšia - ako sme už naznačili - zahŕňa štýl obliekania a neverbálne prejavy mimiky a gestikulácie. Výskumné zistenia Y. Wua a kol. (2014) potvrdzujú, že oba druhy charizmy sa ukazujú ako spôsob prít’ažlivej sily pre dospelých, ktorý ich motivuje k zúčastňovaniu sa na kontinuálnom vzdelávaní. Špeciálne, charizma vyučovacích metód a charizma neverbálnych prejavov sú dva prioritné faktory ovplyvňujúce intenciu dospelých participovat' na d'alšom vzdelávaní. A hoci faktory obliekania sú identifikované ako súčast' charizmy edukátora, nemajú zásadný vplyv na zámer dospelých d’alej sa vzdelávat'. V záveroch svojho príspevku autori uvádzajú okrem iného výzvu pre všetkých vzdelávatel'ov dospelých: „Edukátori už nemôžu d’alej seba samých považovat' za učitel'ov s obmedzenou zodpovednost'ou a autoritou. Mali by sa stat' charizmatickými učitel'mi a hrat' tak rozhodujúcu úlohu v procese celoživotného vzdelávania (Wu, Y. a kol., 2014, p. 400).

\section{Záver}

Kompetenčný profil edukátora preseniorskej prípravy je jedným z kl'účových faktorov, smerujúcich k vyššej kvalite vzdelávacích aktivít pre l'udí v preddôchodkovom veku. Považujeme za potrebné zaoberat' sa vymedzením predpokladov a špecifík, ktoré by mal spĺn̆at' andragóg pracujúci s touto ciel'ovou skupinou práve kvôli tomu, aby vzdelávanie mohlo priniest' želaný efekt a pripravilo staršieho človeka na novú životnú etapu po každej stránke. Vyjadrujeme nádej, že lektorov, školitel'ov či trénerov, ktorí sa rozhodnú k edukácii ,preseniorov“ pristupovat' profesionálne, bude len pribúdat’ a že sa kvalitná príprava na odchod do dôchodku stane jednou z dominantných tém politiky aktívneho starnutia na Slovensku i v Európe.

\section{Acknowledgment}

Článok je výstupom v rámci projektu VEGA č.1/0001/18 s názvom Príprava na starnutie a starobu - možnosti andragogickej intervencie.

The article is the output of author within the project VEGA no.1/0001/18 called Preparation for ageing and old age - possibilities of andragogical intervention

\section{Bibliographic references}

CALLAHAN, J.S. a kol. 2003. Does Method Matter? A Meta-Analysis of the Effects of Training Method on Older Learner Training Performance. In Journal of Management. n. 29, pp. 663-680. Available online: https://www.sciencedirect.com/science/article/abs/pii/S0149206303000291

CORNANICOVA, R. 2007. Geragogika ako teoria edukacie seniorov a edukácie vo vzt’ahu k séniu (Formovanie, terminologia, definícia, status). In: Rocznik Andragogiczny. pp. 163 -173. ISSN 1429-186X

DESPOTOVIC, M. 2012. Vzdelavani dospelych mezi profesionalizaci a profesionalismem. In Studia paedagogica. vol. 46, n. 12, pp. 75-90. ISSN 2336-4521. Available online: 
https://www.phil.muni.cz/journals/index.php/studia-

paedagogica/issue/view/24/showToc

KO, H. 2020. Teaching older adults: an instructional model from Singapore.

In Educational Gerontology. vol.. 46, n. 12, pp. 731-745, ISSN 1521-0472. Available

online:

https://www.tandfonline.com/doi/full/10.1080/03601277.2020.1807689

KUPCOVA, V. 2014. Zaujmove vzdelavanie z aspektu kvality. Banska Bystrica: Belianum, 146 p. ISBN 978-80-557-0744-0.

NARODNA SUSTAVA POVOLANI. 2021. Sektorovo riadene inovacie. Available online: https://sustavapovolani.sk

NARODNY PROGRAM AKTIVNEHO STARNUTIA NA ROKY 20212030 - analyticka cast. 2020. Bratislava: Institut pre vyskum prace a rodiny, 31 p. Available online: https://ivpr.gov.sk/narodny-program-aktivnehostarnutia-na-roky-2021-2030-analyticka-cast-kvetoslava-repkova-ed/.

PATRICIO, M.R. - OSORIO, A.J. 2013. Skills and competences of adult educators: learning experiences with senior citizens. Poster. In Professionalisation of Adult Educators - International and Comparative Perspectives. Bonn, Available online: https://www.researchgate.net/publication/305730306_Skills_and_competenc es_of_adult_educators_learning_experiences_with_senior_citizens

PEJATOVIC, A. 2012. Jake kompetence maji mit vzdelavatele dospelych? In Studia paedagogica, Brno: MUNI. vol. 17, n. 1, pp. 91-111. ISSN 2336-4521. Available online: https://www.phil.muni.cz/journals/index.php/studiapaedagogica/issue/view/24/showToc

WAHLGREN, B. a kol. 2016. Expanding the traditional role of the adult education teacher - The development of relational competences and actions. In Teaching and Teacher Education. vol. 60, pp. 303-311. ISSN 0742-051X. Available online: https://www.sciencedirect.com/science/article/pii/S0742051X16303389?via $\% 3$ Dihub

WU, Y. a kol. 2014. Can Teacher Charisma really Spark Adult Intention in Continuing Learning? In Procedia - Social and Behavioral Sciences. n. 191, pp. 396-401. ISSN 1877-0428. Available online: https://www.sciencedirect.com/science/article/pii/S187704281502412X

\author{
Mgr. Michal Koricina \\ Department of Education \\ Constantine the Philosopher University in Nitra \\ Dražovská 4, 94974 Nitra \\ Slovakia \\ michal.koricina@ukf.sk
}

